\title{
Analisis Yuridis Kepatuhan Hukum terhadap Karantina Kesehatan (Studi Penelitian Kantor Kesehatan Pelabuhan Kelas II Tanjung Pinang)
}

\author{
Joni Hardi \\ Magister Ilmu Hukum UNIBA Batam \\ Jln merpati Gg kutilang No. 1 kel. Batu IX kec. Tanjung Pinang Timur Kota madya Tanjung pinang- Kepulauan Riau \\ Correspondence email: johardi2906@gmail.com
}

\begin{abstract}
Abstrak. Indonesia terletak di jalur lalu lintas perdangan internasional dengan banyaknya pintu masuk ke wilayah Indonesia, hal ini merupakan faktor risiko untuk terjadinya penyebaran penyakit dan gangguan kesehatan. Jumlah kedatangan dan jenis negara asal kapal dari luar negeri di Kantor Kesehatan Pelabuhan Kelas II Tanjung Pinang meningkat setiap tahunnya. Tujuan penelitian ini adalah mengetahui bagaimana pengaturan hukum karantina kesehatan dipintu masuk pelabuhan di Kantor Kesehatan Pelabuhan Kelas II Tanjung Pinang. Penelitian ini menggunakan pendekatan deskriptif dengan jenis penelitian normatif dan sosiology. Komponen yang diteliti mengenai pengaturan hukum karantina kesehatan, implementasi hukum karantina dalam pengawasan kedatangan kapal laut sesuai/ tidak dengan standar operasional prosedur), serta faktor kendala dalam menjalankan peraturan hukum karantina kesehatan. Hasil penelitian menunjukkan bahwa Undang-Undang Nomor 6 Tahun 2018 tentang Kekarantinaan Kesehatan yang menjadi landasan penyelenggaraan karantina kesehatan telah mengatur penerapan pidana terhadap pelanggaran oleh Penyidik Pegawai Negeri Sipil Kekarantinaan, ditemukan kendala antara lain kurangnya kerjasama antara sektor dalam pelaksanaan karantina disebabkan belum adanya pengaturan hukum yang jelas, serta jumlah sumber daya manusia masih kurang dari segi kualitas/ kompetensi, jumlah sarana dan peralatan masih kurang terutama di wilayah kerja, tingkat kepatuhan petugas masih rendah dan montoring belum terlaksana dengan baik. Kesimpulan dari penelitian ini adalah sudah baiknya pengaturan hukum karantina kesehatan karena ikut diterapkannya pasal pidana terhadap pelaku pelanggaran, namun di perlukan pengaturan hukum antar sektor dalam melaksanakan aturan karantina oleh instansi terkait seerta penambahan sdm yang memiliki kompotensi dibidangnya.
\end{abstract}

Kata Kunci: Kepatuhan; karantina; kesehatan.

Abstract. Indonesia is located in the path of international trade traffic with many entrances to Indonesian territory, this is a risk factor for the spread of diseases and health problems.. The purpose of this study was to find out how the health quarantine legal regulation at the entrance to the port in the Class II Tanjung Pinang Port Health Office. This study uses a descriptive approach to the type of normative research and sociology. implementation of quarantine law in the supervision of ship arrivals in accordance with / not in accordance with standard operating procedures) The results showed that Law Number 6 Year 2018 on Health Quarantine which is the basis of the implementation of health quarantine has governed the criminal application of violations by the Quarantine Civil Servant Investigator, and the number of human resources is still lacking in terms of quality / competence, the number of facilities and equipment is still lacking especially in the work area, The conclusion of this research is the good regulation of the health quarantine law due to the adoption of the criminal article against violators, but it is needed an intersectoral legal regulation in implementing quarantine rules by related agencies as well as the addition of tablespoons that have potential in their fields.

Keywords: Compliance; quarantine; Health.

\section{PENDAHULUAN}

Dengan menunjuk pada Pancasila dan Undang-Undang Dasar Negara Republik Indonesia Tahun 1945, kesehatan merupakan hak asasi manusia dan salah satu unsur kesejahteraan yang harus diwujudkan sesuai dengan cita-cita dan tujuan nasional Indonesia dan kebangkitan kesadaran akan hak-hak asasi manusia, khususnya di bidang kesehatan. ${ }^{1}$ Kesehatan merupakan sesuatu yang bernilai, bahkan sangat penting, begitu vital bagi kehidupan manusia dalam menjalani kehidupan untuk meraih cita-cita atau harapannya, kesehatan sekali lagi sangat penting dan berharga bagi kita sebagai manusia. Tanggungjawab atau kewajiban Pemerintah/Pemerintahan Daerah dalam memajukan atau mengangkat derajat kesehatan merupakan bagian integral dari cita-cita dan tujuan nasional. Ini sejalan dengan Peraturan Pemerintah Nomor 46 Tahun 2014 tentang sistem informasi kesehatan yang menyatakan pembangunan pada hakikatnya adalah upaya yang dilaksanakan oleh semua komponen bangsa dalam rangka mengangkat derajat kesehatan dan martabat bangsa. Tujuan intinya adalah meningkatkan kesadaran, kemauan dan kemampuan hidup sehat bagi setiap orang. Pemerintah harus disadarkan agar terus menerus melalui Kementerian Kesehatan meningkatkan kualitas pelayanan dan kualitas tenaga kesehatan. ${ }^{2}$

\footnotetext{
${ }^{1}$.Anny Isfandyarie,, Malapraktek dan Resiko Medik dalam Kajian Hukum Pidana, Prestasi Pustaka, Jakarta, 2005, hlm 24.

${ }^{2}$ A.Ridwan M, Surveilans Kesehatan Masyarakat, Sinar Grafika, Jakarta, 1992,hlm 395.
} 
Tanggungjawab Pemerintah Pusat dalam hal menyelenggarakan Kekarantinaan Kesehatan di Pintu Masuk dan di wilayah secara terpadu yang mana dalam penyelenggaraanya dapat melibatkan Pemerintah Daerah guna pelaksanaan perlindungan kesehatan masyarakat dari penyakit dan/atau faktor risiko kesehatan masyarakat yang berpotensi menimbulkan Kedaruratan Kecemasan Masyarakat (KKM) melalui penyelenggaraan Kekarantinaan Kesehatan. Upaya Kesehatan adalah setiap kegiatan dan/atau serangkaian kegiatan yang dilakukan secara terpadu, terintegrasi dan berkesinambungan untuk memelihara dan meningkatkan derajat kesehatan masyarakat dalam bentuk pencegahan penyakit, peningkatan kesehatan, pengobatan penyakit, dan pemulihan kesehatan oleh pemerintah dan/atau masyarakat.

Asas dan tujuan yang menjadi landasan dan memberikan arah pembangunan kesehatan yang dilaksanakan melalui upaya kesehatan untuk meningkatkan kesehatan, kemauan, dan kemampuan hidup sehat bagi orang sehingga terwujud derajat kesehatan masyarakat yang optimal tanpa membedakan status sosialnya ,hak dan kewajiban setiap orang untuk memperoleh derajat kesehatan yang optimal serta wajib untuk ikut serta di dalam memelihara dan meningkatkan derajat kesehatan.

Pemerintah Pusat dan Pemerintah Daerah bertanggung jawab menyelenggarakan Pengawasan di Bidang Kesehatan, Penyelenggaraan Pengawasan di Bidang Kesehatan bertujuan untuk memastikan dilaksanakannya ketentuan peraturan perundang-undangan di bidang kesehatan oleh masyarakat dan setiap penyelenggara kegiatan yang berhubungan dengan Sumber Daya di Bidang Kesehatan dan Upaya Kesehatan. ${ }^{3}$ Objek pengawasan di bidang kesehatan meliputi masyarakat dan setiap penyelenggara kegiatan yang berhubungan dengan sumber daya di bidang kesehatan dan upaya kesehatan.

Perlu ditambahkan bahwa terdapat 4 faktor yang mempengaruhi status derajat kesehatan yaitu berkaitan dengan gaya hidup (life style), berkaitan dengan faktor lingkungan baik sosial, ekonomi, politik dan budaya, berkaitan dengan faktor genetik (keturunan) dan juga berkaitan dengan faktor kualitas pelayanan kesehatan, maka sebaiknya masyarakat secara sendiri-sendiri yang ingin hidup sehat harus mengendalikan dirinya tanpa dipengaruhi oleh perilaku masyarakat sekitar. Berdasarkan sifat pelayanan kesehatan dapat dibedakan menjadi sebagai berikut; Pelayanan dasar yaitu mencakup pelayanan kesehatan preventif dan kuratif yang diselenggarakan khusus untuk diri sendiri dan untuk lingkungan sekitarnya demi peningkatan kesehatan dan pelenyapan ancaman ganguan kesehatan. Pelayana ambuletor (ekstra mural) yaitu mencakup pelayanan kesehatan spesialistis dan nonspesialistis. Dalam hal anggota masyarakat memperoleh pelayanan kesehatan di semua lembaga, Pelayanan intramural yaitu mencakup penyelenggaraan pelayanan medis umum dan specialistis didalam lembaga. ${ }^{4}$

\section{METODE \\ Pendekatan Penelitian}

Penelitian ini bersifat deskriptif analisis, yaitu penelitian yang mengusahakan untuk melukiskan fakta-fakta yang nyata dan situasi yang berkenaan dengan pengaturan kepatuhan hukum terhadap karantina kesehatan dikantor kesehatan pelabuhan Kelas II Tanjung Pinang.

\section{Sumber Data dan Alat Pengumpulan Data}

Sumber data dalam penelitian ini adalah data primer dan data sekunder. Data primer yang bersumber dari berbagai kebijakan dan peraturan yang dikeluarkan bidang hukum. Pengumpulan data sekunder dilakukan melalui penelitian kepustakaan dengan cara mengkaji buku-buku, jurnal, hasil penelitian, konvensi dan peraturan perundangundangan serta melalui media internet berkenaan dengan hal yang berhubungan dengan permasalahan penelitian. ${ }^{5}$ Data primer diperoleh dengan melakukan Penelitian lapangan dengan cara mewawancarai pihak informan dan responden yang berkaitan dengan objek penelitian ini. ${ }^{6}$ Adapun yang menjadi informan dan responden seperti Indra Utama Tarigan, SKM, Mkm, selaku Kordinator Penyidik Pegawai Negeri Sipil berserta Bapak Kusna Ramdani, SKM, Mkes, selaku Kordinator Seksi Pengendalian Resiko Lingkungan Kantor Kesehatan Pelabuhan.

\section{HASIL DAN PEMBAHASAN}

Pembangunan masyarakat Indonesia sebagai salah satu pelaksanaan kebijakan pemerintah dibidang pembangunan kesehatan masyarakat telah menghasilkan banyak kemajuan, diantaranya telah meningkatkan kesejahteraan rakyat. Kesejahteraan tersebut harus dapat dinikmati secara berkelanjutan, adil, dan merata menjangkau seluruh rakyat. Undang-Undang Nomor 6 Tahun 2018 tentang Kekarantinaan Kesehatan ini telah disahkan oleh

\footnotetext{
${ }^{3}$ Peraturan Menteri Kesehatan Nomor. 10 Tahun 2018

${ }^{4}$ Amir Amri, Bunga Rampai Hukum Kesehatan, Widya Medika, Jakarta, 1996, hlm 16.

${ }^{5}$ Koentjaraningrat, Metode-Metode Penelitian Masyarakat, Gramedia, Jakarta, 1990, hlm 95

${ }^{6}$ Idham, 2010, Konsolidasi Tanah Perkotaan Dalam Perspektif Otonomi Daerah Untuk Mewujudkan Kemampuan Fungsi Lingkungan Hidup, Alumni, Bandung, 2010, hlm 21.
} 
Presiden Republik Indonesia Joko Widodo pada bulan Agustus tahun 2018 yang lalu Undang-Undang ini, sudah berproses sejak kurang lebih 10 tahun yang lalu untuk memperkuat keamanan dan kedaulatan kesehatan negara kita dari ancaman penyakit dan/atau faktor risiko kesehatan yang berpotensi menimbulkan Kedaruratan Kesehatan Masyarakat, baik di pintu masuk negara maupun di wilayah. Penyelenggaraan kekarantinaan kesehatan bertujuan untuk melindungi, mencegah, dan menangkal dari penyakit dan/atau faktor risiko kesehatan masyarakat yang berpotensi menimbulkan kedaruratan kesehatan masayarakat dalam rangka meningkatkan ketahanan nasional di bidang kesehatan secara terpadu, dan dapat melibatkan Pemerintah Daerah, penyelenggaraan kesehatan itu haruslah dilaksanakan berazaskan pada perikemanusiaan, manfaat, perlindungan, keadilan, non diskriminatif, kepentingan umum, keterpaduan, kesadaran hukum, dan kedaulatan negara. Untuk itu dukungan semua pihak dalam penyelenggaraan kekarantinaan kesehatan sangat diperlukan baik dari pemerintah, sektor swasta, maupun elemen masyarakat.

Isolasi pemisahan orang sakit dari orang sehat yang dilakukan difasilitas pelayanan kesehatan bertujuan untuk mendapatkan pengobatan dan perawatan dengan melalui pemeriksaaan kesehatan berupa tindakan dari petugas kesehatan untuk menentukan keadaan sehat atau terjangkitnya seseorang dipelabuhan, bagasi, kontainer alat angkut atau barang bawaan lainnya untuk memperoleh izin karantina untuk masuk atau keluar dari area pelabuhan. Peran dan fungsi karantina dalam era globalisasi saat ini menjadi sangat krusial dan strategis. Paradigma pengelolaanya berubah dari karantina sebagai agen yang pasif menjadi agen yang aktif seiring dengan perubahan paradigma kebijakan perdagangan ke arah Non Tariff Barrier (NTB). Aturan mainnya ditentukan dan disepakati melalui Agreementon sanitary and phytosanitary (SPS) Measures di bawah perjanjian World Trade Organization (WTO) sehingga pengelolaan karantina dapat berjalan efektif dan efisien dengan standar internasional berdasarkan prinsip-prinsip ilmiah. Pada kesepakatan tersebut dinyatakan bahwa dalam kegiatan perdagangan internasional, suatu negara berhak untuk melindungi kesehatan manusia, hewan, dan tumbuhan.

Menurut Beghin and Melatos suatu rezim karantina akan sangat mempengaruhi perdagangan dan juga kesejahteraan pelaku ekonominya. Ada dua jenis tindakan karantina yaituu: Karantina Absolut atau Karantina Lengkap ialah pembatasan ruang gerak terhadap mereka yang telah terpapar dengan penderita penyakit menular. Lamanya pembatasan ruang gerak ini tidak lebih dari masa inkubasi terpajang penyakit menular tersebut. Tujuan dari tindakan ini adalah untuk mencegah orang ini kontak dengan orang lain yang belum terpapar. ${ }^{7}$ Karantina yang dimodifikasi adalah suatu tindakan selektif berupa pembatasan gerak bagi mereka yang terpapar dengan penderita penyakit menular. Biasanya pertmbangannya adalah perkiraan terhadap adanya perbedaan tingnkat kerentanan terhadap bahaya penularan. Modifikasi ini dilakukan untuk menghadapi situasi tertentu.

Kekarantinaan Kesehatan berasaskan kepada perikemanusiaan, kemanfaatan, pelindungan, keadilan; nondiskriminatif, kepentingan umum, keterpaduan, kesadaran hukum; dan kedaulatan negara ,maka Pentingnya karantina kesehatan memerlukan landasan hukum yang jelas, tegas, dan menyeluruh guna menjamin kepastian hukum dalam bentuk undang-undang sebagai dasar penyelenggaraannya. ${ }^{8}$ Hukum nasional yang menjadi landasan penyelenggaraan karantina kesehatan mengatur tentang penerapan pidana terhadap pelanggaran ketentuan undangundang ini, yang dilaksanakan Penyidik Pegawai Negeri Sipil Kekarantinaan Kesehatan yang selanjutnya disebut PPNS.

PPNS Kekarantinaan Kesehatan berwenang: ${ }^{9}$ menerima laporan tentang adanya tindak pidana di bidang Kekarantinaan Kesehatan, mencari keterangan dan alat bukti, melakukan tindakan pertama di tempat kejadian, melarang setiap orang meninggalkan atau memasuki tempat kejadian perkara untuk kepentingan penyidikan, memanggil, memeriksa, menggeledah, menangkap, atau menahan seseorang yang disangka melakukan tindak pidana di bidang Kekarantinaan Kesehatan, menahan, memeriksa, dan menyita dokumen; menyuruh berhenti orang yang dicurigai atau tersangka dan memeriksa identitas dirinya; memeriksa atau menyita surat, dokumen, atau benda yang ada hubungannya dengan tindak pidana Kekarantinaan Kesehatan, memanggil seseorang untuk diperiksa dan didengar keterangannya sebagai tersangka atau saksi; mendatangkan ahli yang diperlukan dalam hubungannya dengan pemeriksaan perkara, melakukan pemeriksaan di tempat tertentu yang diduga terdapat surat, dokumen, atau benda lain yang ada hubungannya dengan tindak pidana di bidang Kekarantinaan Kesehatan, mengambil foto dan sidik jari tersangka, meminta keterangan dari masyarakat atau sumber yang berkompeten, menghentikan

7. John C. Beghin and Mark Melatos, The Trade and Welfare Impact of Australian Quarantine Policies: The Case of Pigmeat, Working Paper No. 11014, Iowa State University, Lowa, 2011, hlm 22.

${ }^{8}$. Undang-Undang Negara Republik Indonesia Nomor 16 Tahun 2018 tentang Kekarantinaan Kesehatan, Pasal 1 angka 32 PPNS adalah pejabat pegawai negeri sipil tertentu yang diberi wewenang khusus oleh Undang-Undang ini untuk melakukan penyidikan tindak pidana di bidang Kekarantinaan Kesehatan.

9. Undang-Undang Negara Republik Indonesia Nomor 16 Tahun 2018 tentang Kekarantinaan Kesehatan, Pasal 1 angka 32 PPNS adalah pejabat pegawai negeri sipil tertentu yang diberi wewenang khusus oleh Undang-Undang ini untuk melakukan penyidikan tindak pidana di bidang Kekarantinaan Kesehatan. 
Joni Hardi, Analisis Yuridis Kepatuhan Hukum terhadap Karantina Kesehatan (Studi Penelitian Kantor Kesehatan Pelabuhan Kelas II Tanjung Pinang)

penyidikan apabila tidak terdapat cukup bukti yang membuktikan adanya tindak pidana di bidang Kekarantinaan Kesehatan; dan/atau mengadakan tindakan lain menurut hukum.

PPNS Kekarantinaan Kesehatan dapat melaksanakan kerja sama dalam penyelidikan dan penyidikan tindak pidana Kekarantinaan Kesehatan dengan lembaga penegak hukum dalam negeri dan negara lain sesuai dengan ketentuan peraturan perundang-undangan mengenai administrasi penyidikan atau berdasarkan perjanjian internasional yang telah diakui oleh Pemerintah Republik Indonesia. Setiap orang yang tidak mematuhi penyelenggaraan Kekarantinaan Kesehatan sebagaimana dimaksud dalam Pasal 9 ayat (1) dan /atau menghalang-halangi penyelenggaraan Kekarantinaan Kesehatan sehingga menyebabkan Kedaruratan Kesehatan Masyarakat dipidana dengan pidana penjara paling lama1 (satu) tahun dan /atau pidana denda paling banyak Rp100.000.000,00 (seratus juta rupiah).

PPNS Kekarantinaan Kesehatan dapat melaksanakan kerja sama dalam penyelidikan dan penyidikan tindak pidana Kekarantinaan Kesehatan dengan lembaga penegak hukum dalam negeri dan negara lain sesuai dengan ketentuan peraturan perundang-undangan mengenai administrasi penyidikan atau berdasarkan perjanjian internasional yang telah diakui oleh Pemerintah Republik Indonesia. ${ }^{10}$ Pemerintah dalam menjalankan hukum pidana senantiasa dihadapkan pada suatu paradoxalitiet yang oleh Hazewinkel-Suringa dilukiskan sebagai berikut: "pemerintah negara harus menjamin kemerdekaan individu, menjaga supaya pribadi manusia tidak disinggung dan tetap dihormati. Namun, kadang-kadang sebaliknya pemerintah negara menjatuhkan hukuman kepada pribadi manusia, misalnya, memenjarakan yang bersangkutan. Jadi, di satu pihak, pemerintah negara membela dan melindungi pribadi manusia terhadap serangan ${ }^{11}$.

Pasal-pasal yang disebutkan dalam ketentuan pidana memuat norma yang harus dipenuhi bagi setiap media pembawa penyakit hewan karantina, terhadap pelaksanaan norma tersebut, apabila dilakukan pengawasan dengan baik oleh petugas karantina, maka dapat dicegah terjadinya pelanggaran, yang tidak memenuhi persyaratan karantina tidak diperbolehkan masuk ataupun keluar dari wilayah RI. Fungsi Karantina dilaksanakan dengan melakukan tindakan karantina, yaitu melakukan pemeriksaan, pengasingan, pengamatan, perlakuan, penahanan, penolakan, pemusnahan dan pembebasan terhadap kedaruratan kesehatan masyarakat. Dari sisi operasional yang juga berdasarkan hukum internasional, salah satu sistem operasional Custom, Immigration, and Quarantine (CIQ) di setiap pintu masuk dan keluar termasuk pos perbatasan sebagai pelaksana law enforcement terhadap pengawasan lalu lintas. Pada dasarnya karantina ini memiliki prospek yang sangat baik bagi pertumbuhan dan kemajuan kesehatan di Indonesia, apabila badan karantina ini berfungsi dengan baik. ${ }^{12}$

Suatu pelabuhan dan/atau daerah wilayah Indonesia ditetapkan terjangkit penyakit karantina, bila di pelabuhan dan/atau daerah wilayah itu terdapat: seorang penderita penyakit karantina yang bukan berasal dari luar pelabuhan atau daerah wilayah itu; tikus berpenyakit pes di daratan atau di kapal yang termasuk perlengkapan pelabuhan; binatangbinatang yang bertulang punggung yang mengandung virus penyakit demam kuning yang aktif; wabah tifus bercak wabah atau demam balik-balik. Dipelabuhan Indonesia, yang ditetapkan terjangkit penyakit karantina, ditempatkan untuk kapal tanda-tanda karantina sebagai berikut pada siang hari; bendera Q (kuning); pada malam hari; dua lampu putih, yang satu ditempatkan diatas yang lain dengan jarak dua meter yang tampak dari jarak 2 (dua) mil. Untuk pemeriksaan kesehatan dan pelaksanaan tindakan karantina Menteri Kesehatan menggolongkan pelabuhan-pelabuhan Indonesia dalam: Pelabuhan karantina kelas I, dimana dokter pelabuhan dapat menyelenggarakan tindakan karantina sepenuhnya. Pelabuhan karantina kelas II, dimana dokter pelabuhan dapat menyelenggarakan sebagian dari tindakan karantina. ${ }^{13}$

Untuk kapal yang dikenakan pemeriksaan kesehatan diisi suatu keterangan kesehatan maritim yang harus diberikan kepada dokter pelabuhan oleh nakhoda mengenai keadaan kesehatan di kapal. Tiap penumpang dan awak kapal dari suatu kapal yang ada di dalam perjalanan internasional diharuskan memiliki keterangan vaksinasi cacar yang berlaku; Menteri Kesehatan menetapkan bentuk dan isi keterangan vaksinasi tersebut. Tiap kapal harus memiliki surat keterangan hapus-tikus/atau surat keterangan bebas hapus-tikus; bentuk dan isi surat keterangan tersebut ditetapkan oleh Menteri Kesehatan. Dokumen-dokumen tersebut tentang bentuk dan isinya disesuaikan dengan bentuk-bentuk yang dilampirkan pada "International Sanitary Regulations 1951".

Kapal yang berbendera Indonesia dan kapal yang melakukan pelayaran pantai di dalam wilayah Indonesia, harus mempunyai suatu buku kesehatan, yang bentuk dan isinya ditetapkan oleh Menteri Kesehatan. Dengan tata cara dan tindakan sebagai berikut; Tata-cara pada kedatangan kapal. Tiap kapal yang datang dari luar negeri berada dalam karantina. Tiap kapal yang datang dari suatu pelabuhan dan/atau daerah wilayah Indonesia yang ditetapkan terjangkit suatu penyakit karantina berada dalam karantina. Tiap kapal yang mengambil penumpang dan/atau muatan dari kapal yang disebut dberada dalam karantina. Kapal yang disebut baru bebas dari karantina, bila telah mendapat surat izin karantina.

\footnotetext{
${ }^{10}$.Undang-Undang Negara Republik Indonesia No. 6 Tahun 2018 tentang Kekarantinaan Kesehatan, Pasal 87.

${ }^{11}$ Muladi dan Barda Nawawi, , Teori-teori dan Kebijakan Pidana, Alumnim Bandung, 1998, hlm 149.

${ }^{12} \mathrm{http} / / / \mathrm{www}$.depkes. go.id

${ }^{13}$.Undang-Undang Republik Indonesia Nomor 1 Tahun 1962 tentang Karantina Laut, Pasal 14
} 
Kerjasama lintas sektor adalah suatu kerjasama yang terbentuk dengan lintas sektor di pelabuhan dalam rangka pengawasan kedatangan kapal laut dari dalam maupun luar negeri. Kerjasama dengan lintas sektor di Kantor Kesehatan Pelabuhan Kelas II Tanjung Pinang secara umum selama ini sudah berjalan dengan baik karena selalu melibatkan lintas sektor yang ada di wilayah kerja Kantor Kesehatan Pelabuhan Kelas II Tanjung Pinang baik di pelabuhan mapun di bandara dalam setiap acara seperti sosialisasi, pertemuan koordinasi, coffee morning, rapat lintas sektor lainnya.

Jika ada peraturan atau kebijakan yang baru maka Kantor Kesehatan Pelabuhan Kelas II Tanjung Pinang segera mengundang seluruh lintas sektor yang terkait baik di pelabuhan laut maupun di bandara untuk dilakukan sosialisasi agar semua lintas sektor dapat memahami peraturan atau kebijakan tersebut sehingga dalam melakukan tugas di lapangan masing-masing instansi tahu dengan tupok pokok dan fungsinya serta wewenang dan tanggungjawabnya, sehingga diharapkan tidak terjadi konflik kepentingan dalam melaksanakan tugas di lapangan. ${ }^{14}$

Kewenangan Kantor Kesehatan Pelabuhan sebagai lembaga yang melaksanakan penyelenggaraan karantina kesehatan di pintu masuk dan keluar alat angkut beserta muatannya sangat terbatas. Hal ini disebabkan kegiatan penyelenggaraan karantina kesehatan berkaitan dengan tugas dan fungsi sektor lainnya, akibatnya sering ditemukan kesulitan di lapangan terutama dalam hal koordinasi. Sementara itu, objek pengawasan karantina kesehatan dalam upaya mengantisipasi ancaman terjadinya kondisi PHEIC semakin luas. Untuk mengatasi permasalahan tersebut diperlukan adanya pengaturan yang mampu mendorong adanya koordinasi antar sektor dalam penyelenggaraan karantina kesehatan dan penguatan dari lembaga yang ada saat ini.

Izin lepas karantina diberikan oleh dokter pelabuhan setelah dilakukan pemeriksaan-pemeriksaan dan terdapat bahwa kapal itu sehat atau kalau segala tindakan yang dianggap perlu oleh dokter pelabuhan telah selesai dilakukan. Jika kepada suatu kapal tidak dapat diberikan izin lepas karantina, tetapi dokter pelabuhan berpendap at bahwa bahaya kemasukan serangga suatu penyakit karantina tidak seberapa membahayakan, maka dokter pelabuhan dapat memberikan izin terbatas karantina kepada kapal yang bersangkutan untuk jangka waktu yang tertentu. Jika dalam waktu berlakunya izin lepas dan/atau izin lepas terbatas karantina timbul suatu kematian atau penyakit karena suatu penyakit karantina, izin yang dimaksud tidak berlaku lagi. Dalam hal itu kapal menuju kesuatu pelabuhan karantina untuk mendapat tindakan-tindakan karantina yang diperlukan.

Untuk kapal yang datang dari luar negeri dan akan singgah di suatu pelabuhan bukan pelabuhan karantina dan untuk kapal yang mempunyai pelayaran tertentu antar luar negeri dan pelabuhan-pelabuhan Indonesia bukan pelabuhan karantina oleh Menteri Kesehatan dapat diberikan surat izin sementara karantina tanpa dibebaskan dari tindakan karantina. Surat izin yang dimaksudkan dapat diberikan atas permintaan perusahaan pelayaran kapal tersebut yang bertempat kedudukan di Indonesia atau mempunyai hubungan lalu-lintas pelayaran tetap dengan tempat-tempat tertentu. ${ }^{15}$

Kepada kapal yang tidak mau tunduk pada peraturan karantina tidak diberikan "izin karantina"; kepadanya diperintahkan supaya berangkat lagi atas tanggungan sendiri dan tidak diizinkan memasuki pelabuhan lain di Indonesia. Kapal tersebut diizinkan mengambil bahan bakar, air dan bahan makanan di bawah pengawasan dokter pelabuhan. Kapal yang tersebut yang terjangkit demam kuning terhadapnya dilakukan tindakan karantina. Pemeriksaan kesehatan atas suatu kapal oleh dokter pelabuhan dilakukan secepat mungkin kecuali kalau keadaan cuaca tidak mengizinkan. Urutan pemeriksaan yang dimaksudkan ditetapkan dokter pelabuhan. Nakhoda kapal menyampaikan segala keterangan kepada dokter pelabuhan dan memberi segala bantuan yang diminta oleh penjabat tersebut. Jika di kapal bekerja seorang dokter kapal, maka dokter tersebut ikut serta melakukan pemeriksaan kesehatan.

\section{SIMPULAN}

Pembangunan masyarakat Indonesia sebagai salah satu pelaksanaan kebijakan pemerintah dibidang pembangunan kesehatan masyarakat telah menghasilkan banyak kemajuan, diantaranya telah meningkatkan kesejahteraan rakyat. Kesejahteraan tersebut harus dapat dinikmati secara berkelanjutan, adil, dan merata menjangkau seluruh rakyat. Undang-Undang Nomor 6 Tahun 2018 tentang Kekarantinaan Kesehatan ini telah disahkan oleh Presiden Republik Indonesia Joko Widodo pada bulan Agustus tahun 2018 yang lalu. Undang-Undang ini, sudah berproses sejak kurang lebih 10 tahun yang lalu untuk memperkuat keamanan dan kedaulatan kesehatan negara kita dari ancaman penyakit dan/atau faktor risiko kesehatan yang berpotensi menimbulkan Kedaruratan Kesehatan Masyarakat, baik di pintu masuk negara maupun di wilayah. Penyelenggaraan kekarantinaan kesehatan bertujuan untuk melindungi, mencegah, dan menangkal dari penyakit dan/atau faktor risiko kesehatan masyarakat yang berpotensi

\footnotetext{
${ }^{14}$ Fitra Gusfriyanto, Rizanda Machmud, Edison, Jurnal Analisis Pelaksanaan Program Pengawasan Kedatangan Lapal Laut Dari Luar Negeri di Kantor Kesehatan Pelabuhan Kelas II Tanjung Pinang, Jurnal Hukum, 2017, hlm 7-8.

${ }^{15}$ Alexandra Indriyanti Dewi,2008, Etika dan Hukum Kesehatan, Pustaka Book Publisher, Sleman, Yogyakarta, 2008,22
} 
menimbulkan kedaruratan kesehatan masayarakat dalam rangka meningkatkan ketahanan nasional di bidang kesehatan secara terpadu, dan dapat melibatkan Pemerintah Daerah, penyelenggaraan kesehatan itu haruslah dilaksanakan berazaskan pada perikemanusiaan, manfaat, perlindungan, keadilan, non diskriminatif, kepentingan umum, keterpaduan, kesadaran hukum, dan kedaulatan negara. Untuk itu dukungan semua pihak dalam penyelenggaraan kekarantinaan kesehatan sangat diperlukan baik dari pemerintah, sektor swasta, maupun elemen masyarakat

\section{DAFTAR PUSTAKA}

\section{Buku}

Anny Isfandyarie,2005, Malapraktek dan Resiko Medik dalam Kajian Hukum Pidana, Prestasi Pustaka, Jakarta. Alexandra Indriyanti Dewi,2008, Etika dan Hukum Kesehatan, Pustaka Book Publisher, Sleman, Yogyakarta. Amir Amri, 1991, Bunga Rampai Hukum Kesehatan, Widya Medika, Jakarta.

A.Ridwan M, 1991, Surveilans Kesehatan Masyarakat, Sinar Grafika, Jakarta.

John C. Beghin and Mark Melatos, 2011, The Trade and Welfare Impact of Australian Quarantine Policies: The Case of Pigmeat, Working Paper No. 11014, Iowa State University, Lowa.

Koentjaraningrat, 1990, Metode-Metode Penelitian Masyarakat, Gramedia, Jakarta

Idham, 2010, Konsolidasi Tanah Perkotaan Dalam Perspektif Otonomi Daerah Untuk Mewujudkan Kemampuan Fungsi Lingkungan Hidup, Alumni, Bandung.

Muladi dan Barda Nawawi, 1998, Teori-teori dan Kebijakan Pidana, Alumnim Bandung.

\section{Konvensi, Undang-Undang dan Peraturan}

Undang-Undang Nomor 1 Tahun 1962 tentang Karantina Laut

Undang-Undang Nomor 6 Tahun 2018 tentang Kekarantinaan Kesehatan (Lembar Tambahan Berita Negara No.6236)

Peraturan Menteri Kesehatan Republik Indonesia Nomor 10 Tahun 2018 tentang Pengawasan di Bidang Kesehatan.

Penjelasan Atas Undang-Undang Republik Indonesia Nomor 6 Tahun 2018 tentang Kekarantinaan Kesehatan.

\section{Makalah}

Fitra Gusfriyanto, Rizanda Machmud, Edison, 2017, Jurnal Analisis Pelaksanaan Program Pengawasan Kedatangan Lapal Laut Dari Luar Negeri di Kantor Kesehatan Pelabuhan Kelas II Tanjung Pinang, Jurnal Hukum.

\section{Internet}

http://www.dcp2.org.id 